\title{
Disseminated Superficial Porokeratosis with Dermal Amyloid Deposits
}

\author{
M. Carlesimo ${ }^{a}$ \\ A. Rossi ${ }^{b}$ \\ L. Fidanza ${ }^{a}$ \\ A. Narcisi ${ }^{\mathrm{a}}$ \\ M. La Pietra ${ }^{a}$ \\ E. Maria \\ C. Cacchic \\ G. Camplone ${ }^{a}$ \\ aU.O.C. Dermatology, II Unit University of Rome 'Sapienza', 'bepartment of \\ Dermatology and Venereology, I Unit University of Rome 'Sapienza', and \\ 'Department of Histopathology, II Unit University of Rome 'Sapienza', Rome, Italy
}

\section{Key Words}

Porokeratosis · Amyloidosis · Cytokeratin · Anticytokeratin antibodies

\begin{abstract}
Only 6 cases with an association of disseminated superficial porokeratosis with dermal amyloid deposits are reported in the literature. We present the case of a 76-year-old woman who presented with a disseminated superficial porokeratosis. Histological examination revealed amyloid deposits in the upper dermis, which were typed with routine HE stains, Congo red stains and anticytokeratin antibodies (AE1-AE3 and CK5). Positive staining with Congo red and, moreover, with CK5 (a cytokeratin strongly represented in the basal cell layer of the epidermis) indicates an epidermal origin of this protein.
\end{abstract}

\section{Introduction}

Porokeratoses are a group of cutaneous entities of unknown etiology, characterized by disordered epidermal keratinization and, at histological examination, by the presence of coronoid lamella, a column of parakeratotic cells extending through the stratum corneum [1].

Disseminated superficial porokeratosis (DSP) is a distinct form of porokeratosis that, clinically, is characterized by numerous, small, superficial keratotic papules with verrucoid aspects, an atrophic center and peripheral keratotic border. Sometimes DSP can be associated with dermal amyloid deposits [1]. Only 7 cases of this association have been described in the literature (table 1) [2].

We report a eighth case of this type and an atypical immunohistochemical method used to characterize the amyloid substance. 


\begin{tabular}{l|l|l|l} 
Case Reports $h$ & Case Rep Dermatol 2009;1:35-38 & Published online: September 12, 2009 & $\begin{array}{l}\text { ○ 2009 S. Karger AG, Basel } \\
\text { ISSN 1662-6567 } \\
\text { www.karger.com/cde }\end{array}$ \\
\hline
\end{tabular}

\section{Case Report}

A 76-year-old woman was referred to our Department in June 1999. She reported a 20 years' history of an erythematous and squamo-papular eruption located on the extremities, without itching or pain. The patient had noted a progressive extension of these lesions in the last year and an exacerbation of the lesions during the summer. Upon physical examination, numerous papules with a size of less than 15 $\mathrm{mm}$, an atrophic center and hyperkeratotic borders were distributed on the neck, chest and extremities. Palms, soles, mucous membranes and nails were spared, and the patient denied any family history of similar skin lesions. She had no other symptoms and laboratory tests were all normal or negative.

We examined a skin biopsy that revealed atrophy of the epidermis with hyperorthokeratosis and presence of homogeneous and compact cornoid lamella of keratin, typically oriented sideways with respect to the epidermal tissue (fig. 1a). The superficial dermis showed a slight chronic inflammatory infiltrate with vascular ectasia and edema. Moreover, in the papillary dermis a compact deposit of a cellular eosinophilic material suspicious for amyloid was observed (fig. 1b).

To demonstrate the epithelial origin of the amyloid, we performed two immunohistochemical stainings by using specific MoAbs to pan-cytokeratin AE1-AE3. Interestingly, there was a striking difference between the two results: in fact, the acellular deposits, mentioned above, were negative for CKAE1-AE3, whereas a strong immunoreactivity was demonstrated for CK5, supporting a specific origin of the amyloid substance from the basal cell layer of the epidermis (fig. 1c).

\section{Discussion}

In 1937, Andrews first described DSP and introduced this term to indicate a clinical variant of Mibelli's porokeratosis. Later, Chernoski and Freeman proposed a possible actinic etiology of this dermatosis and coined the term disseminated superficial 'actinic' porokeratosis (DSAP). Nowadays, this term is generally accepted in European dermatological literature, and this definition is based on clinical and histological findings. Dermatological manifestations are typically confined to sun exposed areas, with actinic induction and exacerbations [2].

In the literature, two types of localized cutaneous amyloidosis (LCA) are described: primary LCA (macular amyloidosis and lichen amyloidosis), which is not associated with other dermatoses or systemic involvement, and secondary LCA, which is associated with inflammatory, hamartomatous or neoplastic skin disorders [2].

The mechanism by which DSP induces dermal amyloid deposits is not clear, but Piamphongstant et al. first suggested that this process can derive from degenerated epidermal keratinocytes [2]. We hypothesize that a mutant keratinocyte clone is responsible for induction of porokeratotic lesions, because these necrotic epidermal keratinocytes (colloid bodies) might be transformed into amyloid by dermal macrophages and fibroblasts [3]. Immunohistochemical staining has shown an overexpression of p53 protein in porokeratotic lesions; this is a tumor suppressor protein, an important gatekeeper and effector of the cell cycle. Mutations of the p53 gene in all forms of porokeratosis, also in DSAP, create a permissive state of uncoordinated cell cycling, and predispose cells to death [4].

In our case, the lack of systemic involvement led to our hypothesis of a secondary dermal deposition of amyloid proteins and the existence of a close relationship between these two processes. This hypothesis was confirmed by positive staining with Congo red and immunohistochemical staining with the anticytokeratin MoAbs strongly positive for CK5, just below the epidermal porokeratotic zone in close proximity to the cornoid lamella. This cytokeratin is, in fact, strongly represented in the basal cell layer and these 


\begin{tabular}{c|l|l|l}
$\begin{array}{c}\text { Case Reports in } \\
\text { Denmitolagy }\end{array}$ & $\begin{array}{l}\text { Case Rep Dermatol 2009;1:35-38 } \\
\text { D0I: } 10.1159 / 000236037\end{array}$ & Published online: September 12, 2009 & $\begin{array}{l}\text { O 2009 S. Karger AG, Basel } \\
\text { ISSN 1662-6567 } \\
\text { www.karger.com/cde }\end{array}$ \\
\hline
\end{tabular}

results indicate that the dermal deposits were amyloid originating from the epidermis (type II keratin).

Nowadays, more studies are necessary to clarify the exact mechanism that leads to secondary deposition of dermal amyloid in porokeratotic disease and the frequency of this association. We also suggest utilization of MoAbs for CK5 as a first-line target in these conditions, encouraged by the immediate and strong positivity of this protein in immunohistochemical studies, whereas pan-cytokeratin at first produced negative results.

Table 1. DSP with amyloid deposits: a summary of the reported cases

\begin{tabular}{|c|c|c|c|c|c|c|c|}
\hline & $\begin{array}{l}\text { Piamphongstant } \\
\text { and } \\
\text { Sittapairoachana, } \\
1974 \text { [5] }\end{array}$ & $\begin{array}{l}\text { Stefanato } \\
\text { et al., } \\
1993 \text { [6] }\end{array}$ & $\begin{array}{l}\text { Yasuda } \\
\text { et al., } \\
1996 \text { [7] } \\
\text { 1st case }\end{array}$ & $\begin{array}{l}\text { Yasuda } \\
\text { et al., } \\
\text { 1996 [7] } \\
\text { 2nd case }\end{array}$ & $\begin{array}{l}\text { Amantea } \\
\text { et al., } \\
1998 \text { [3] }\end{array}$ & $\begin{array}{l}\text { Demitsu } \\
\text { and Okada, } \\
1999[8]\end{array}$ & $\begin{array}{l}\text { Kim et al., } \\
2000 \text { [2] }\end{array}$ \\
\hline Age/sex & $51 / \mathrm{F}$ & $32 / \mathrm{F}$ & $63 / \mathrm{M}$ & $60 / \mathrm{M}$ & $72 / \mathrm{M}$ & $63 / \mathrm{M}$ & $88 / \mathrm{M}$ \\
\hline Age at onset & 6th decade & 4th decade & 5th decade & 6th decade & 7th decade & adolescence & 7th decade \\
\hline Duration & 7 years & 1 month & 20 years & 2 years & $3-4$ years & n.d. & 20 years \\
\hline Pruritus & n.d. & none & slight & present & none & n.d. & severe \\
\hline Family history & n.d. & negative & n.d. & n.d. & negative & negative & daughter \\
\hline Treatment & n.d. & $\begin{array}{l}\text { topical } \\
\text { steroid/ } \\
\text { etretinate }\end{array}$ & $\begin{array}{l}\text { topical } \\
\text { DMSO }\end{array}$ & $\begin{array}{l}\text { topical } \\
\text { DSMO } \\
\text { topical } \\
\text { steroid }\end{array}$ & n.d. & cryosurgery & $\begin{array}{l}\text { topical } \\
\text { steroid } \\
\text { antihistamine } \\
\text { cryosurgery }\end{array}$ \\
\hline Results & & $\begin{array}{l}\text { not } \\
\text { improved }\end{array}$ & improved & worsened & & improved & improved \\
\hline
\end{tabular}

n.d. $=$ Not described; $\mathrm{DSMO}=$ dimethyl sulfoxide .

Fig. 1. a Hyperkeratosis and coronoid lamella. b Eosinophilic, acellular deposits in the dermis. c Strong immunoreaction of amyloid for CK5.
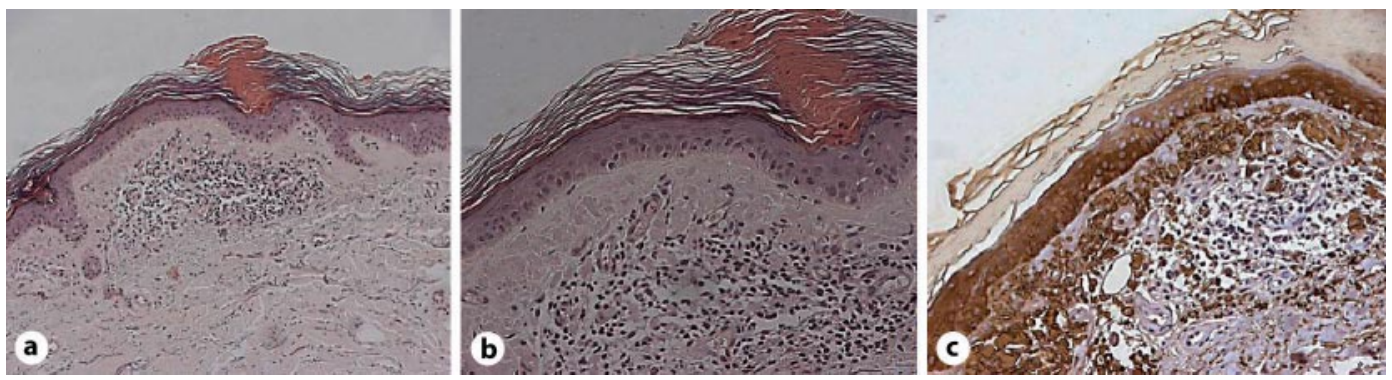


\section{References}

1 Ginarte M, Leòn A, Toribio J: Disseminated superficial porokeratosis with amyloid deposits. Europ J Dermatol 2005;15:298-300.

2 Kim JH, Yim JH, Kang WH: Secondary cutaneous amyloidosis in disseminated superficial porokeratosis: a case report. J Korean Med Sci 2000;15:478-481.

-3 Amantea A, Giuliano MC, Balus L: Disseminated superficial porokeratosis with dermal amyloid deposits: case report and immunohistochemical study of amyloid. Am J Dermatopathol 1998;20:86-88.

4 Arranz-Salas I, Sanz-Trelles A, Bautista-Ojeda D: p53 alterations in porokeratosis. J Cutan Pathos 2003;30:455-458.

5 Piamphongstant T, Sittapairoachana D: Localized cutaneous amyloidosis in disseminated actinic porokeratosis. J Cutan Pathol 1974;1:207-210.

-6 Stefanato CM, Youssef EA, Cerio R, Kobza-Black A, Greaves MW: Atypical Nekam's disease - keratosis lichenoides chronica associated with porokeratosis histology and amyloidosis. Clin Exp Dermatol 1993;18:274-276.

7 Yasuda K, Ikeda M, Kodama H: Disseminated superficial porokeratosis with amyloid deposition. J Dermatol 1996;23:111-115.

8 Demitsu T, Okada O: Disseminated superficial porokeratosis with dermal amyloid deposition. J Dermatol 1999;26:405-406.

All the authors contributed equally to this paper. 